\title{
MASYARAKAT AGAMA HINDUISME DAN BUDDHAISME \\ (KAJIAN SOSIOLOGI AGAMA)
}

Nurul Aeni

\author{
Pascasarjana UIN Sunan Kalijaga Yogyakarta
}

\author{
nurulazmichafunk@gmail.com
}

\begin{abstract}
This article examines Hinduism and Buddhism in the study of the sociology of religion. the concept of religion in the reality of people's lives is often a trigger for conflict due to not understanding one another. So to eradicate religious conflict in a society that claims the truth, it is important to discuss it in the realm of the sociology of religion. Because the sociology of religion plays a role in this. So the purpose of this article is to know how to understand religion in Hinduism, Buddhism and what kind of religious teachings are contained in it. The results of this study indicate that the sociology of religion is able to contribute through the public's perspective on one religion to another. So as to be able to build a harmonious and prosperous life in community life.
\end{abstract}

Keywords: sociology, religion, hinduism and buddhism

\section{Abstrak}

Tulisan artikel ini mengkaji tentang agama hinduisme dan buddhaisme dalam kajian sosiologi agama. konsep agama dalam realitas kehidupan masyarakat sering kali menjadi pemicu terjadinya konflik akbat dari tidak saling memahami satu dengan yang lainnya. Maka untuk memberantas konflik keagamaan di tengah masyarakat yang saling mengklaim kebenaran penting untuk di bahas dalam ranah sosiologi agama. Sebab ilmu sosiologi agama mengambil peran dalam hal ini. Sehingga tujuan dari tulisan artikel ini adalah ingin mengetahui bagaimana pemahaman agama dalam agama hinduisme, buddhaisme dan seperti apa ajaran-ajaran keagamaan yang terkandung di dalamnya. Hasil dari penelitian ini menjukkan bahwa sosiologi agama mampu memberikan kontribusinya kepada cara pandang masyarakat terhadap agama yang satu dengan yang lain. Sehingga mampu membangun kehidupan yang rukun dan sejahtera dalam kehidupan masyarakat.

Kata kunci: sosiologi, agama, hinduisme dan buddhaisme

\section{A. PENDAHULUAN}

Kehidupan masyarakat beragama di Indonesia sering disebut dengan multikultualisme yang merangkul tentang keragaman yang ada di Indonesia mulai dari suku, Bahasa, bahkan agama yang tidak dapat kita pungkiri. Dan konflik antara agama sering kali terjadi akibat dari kelaim kebenaran. Maka makna dari multikultual adalah bentuk dari saling menerima satu dengan yang lainya, karena manusia merindukan 
kedamaian dan kasih sayang dalam hidup berdampingan dengan ke khasan warna setiap agama. ${ }^{1}$

Perbedaan agama tidak jarang digunakan sebagai alat menciptakan konflik atas nama membenarkan agama diri sediri dan menganggap agama sendiri yang paling benar kemudian yang lain salah. Selama ini juga masyarakat beragama sering apatis terhadap keragaman agama yang di miliki Indonesia yang membuat penulis ingin memperkenalkan agama Hinduisme dan Buddhaisme yang sama-sama mempunyai ajaran-ajaran agama yang baik terhadap pemeluknya sebagaimana yang terdapat pada agama yang lainnya.

Pada hakikatnya perilaku beragama dalam kehidupan sosial masyarakat hinduisme dan buddhaisme merupakan sebuah ekperisi dari ajaran setiap agama tersebut. Muncul beragama peraktik keagamaan dari keduanya tidak berdasarkan pemahaman secara individu namun atas dasar ajaran dari masing-masing agama yang terdapat dalam al-kitab. Hal ini tidak dapat di pisahkan dari faktor genetis, idologis, sosiologis, psikologis, antropologis dan intektualistas yang di bangun secara turun menurun yang di warisi oleh nenek moyang dari kedua agama tersebut.

Manusia merupakan mahluk hidup yang tinggal dalam sekelompok masyarakat dengan menjalin hubungan satu dengan yang lainnya. Dalam sosiologi kehidupan dalam masyarakat merupakan sebuah filosofis social yang teratur dengan suatu system nilai, norma, adat istihadat, bahkan agama yang mereka yakini akan mempengaruhi perilaku kehidupan mereka.

Agama dalam kehidupan manusia sangat penting dan agama telah mengatur kehidupan manusia. Agama mengajarkan kepada manusia bagaimana menjalin hubungan dengan sesama dan menjalin hubungan dengan Tuhannya. Kemudian yang paling utama adalah agama sebagai pedoman hidup manusia dan setiap agama mengajarkan kebaikan kepada umatnya. ${ }^{2}$

Setiap orang mendambakan kebahagian dan keselamatan dalam hidupnya dan setiap agama mengajarkan kebaikan dan menjanjikan keselamatan dan kebagaian dunia akhirat kepada setiap pemeluknya yang taat terhadap ajaran agamanya. Kemudian setiap agama mempunyai persektif masing-masing dalam memaknai konsep keselamatan dalam ajaran agamanya. Di Indonesia sendiri terdapat enam macam agama yang mendifisikan konsep keselamatan dengan berbeda-beda.

Misalnya agama Islam mendifisikan keselamatan dalam mendapatkan pengampunan dan kasih sayang dari Tuhan dengan melalukan perintah dan menjauhkan larangaan nya. Sehingga mendapatkan ketenangan, kedamaian,

\footnotetext{
${ }^{1}$ Yuliana, "Menjaga Kerukunaan Dalam Multikulturalisme Beragama: Universitas Udayana Prosiding Webinar Nasional IANH-TP Palangkaraya", No.2 Tahun (2021), 1-2 [Https://Prosiding.lahntp.Ac.Id, ISBN: 978-623-90547-8-6,].

${ }^{2}$ Kadek Widiaastuti, "Hubungan Agama Dalam Kehidupan Masyarakat Bali”, VIDYA DARS'AN: Jurnal Mahasiswa Filsafat Hindu, Volume 2, No. 1 (November 2020), 1.
} 
ketenteraman dengan menyerahkan diri kepada Tuhan dan Rasulnya. Kristen keselamatan adalah mendapatkan penebusaan dosa, yang di tandai dengan keselamatan ketika ia mengimani dan mempercayai bahwa yesus adalah perantara menuju keselamatan. ${ }^{3}$ Dari kedua contoh tersebut sudah terlihat bagaimana setiap agama mempunyai konsep tersendiri dalam memahami keselamatan dalam agama.

Penelitian ini menggunakan metode kajian literatur dalam mengumpulkan data peneliti menggunakan buku, jurnal, artikel, skripsi dan situs-situs di internet dengan tujuan mengetahui bagaimana masyarakat hinduisme dan budhaisme dalam ruang lingkup ajaran agamanya. Melalui hasil bacaan dan analisis data dari perpustakaan digital yang berhubungan dengan tema yang di bahas.

\section{B. HASIL DAN DISKUSI}

\section{Agama Dalam Masyarakat}

Agama dan masyarakat merupakan dua hal yang tidak bisa di pisahkan. Agama dalam kehidupan masyarakat mengandung beberapa unsur yang terdiri dari kepercayaan terhadap segala sesuatu yang sakral, adanya peraktik ritual yang sakral dan adanya komunitas dari setiap pemeluk agama. Sakral dalam ranah agama merupakan suatu kepercayaan yang membentuk keyakinan keagamaan setiap pemeluknya. Kemudian unsur dari ritual merupakan praktik keagamaan yang di dalamnya terdapat simbol-simbol yang mempunyai makna tertentu dan memberikan ekspresi dan manipestasi terhadap keyakinan yang sakral. Misalnya dalam agama Islam simbol dari pada shalat adalah bentuk dari pada ketundukan kepada yang saktral. Dan Setiap agama dalam masyarakat mengandung norma-norma tertentu yang mengatur kehidupan para pemeluknya. 4

Agama dalam masyarakat memberikan arahan terhadap proses perjalanan hidup manusia. James Redfield mengatakan agama yang mengarahkan manusia kepada tingkah laku yang berhubungan jiwa dengan jiwa yang tersembunyi. Agama juga menjadi pendorong manusia terhadap dirinya sendiri, kemudian perilaku, perasaan yang berhubungan dengan manusia lainnya yang dapat di jumpai dalam kehidupan masyarakat. 5

Agama dalam kehidupan masyarakat sangat erat keduanya saling berhubungan. Hal ini dapat kita lihat pada peraktek-peraktek keagamaan yang dilakukan masyarakat. Agama menjadi kebutuhan dalam kehidupan masyarakat. Hal ini terlihat pada perilaku-perilaku keagamaan masyarakat, dimana masyarakat selalu melakukan peraktik-peraktik keagamaan berdasarkan ajaran agama ynag dianutnya

${ }^{3}$ Bubun Bunyamin, "Konsep Keselamataan Dalam Agama-Agama Ibrahim (Yahudi, Kristen, Dan Islam)", (Skripsi: Uinversitas Islam Negeri Sunan Gunung Jati Bandung, 2013), 5-13.

${ }^{4}$ Adi Rahmat \& Rosita Andini, "Pengantar Sosiologi Agama", (Jakarta: Lpp Press, 2015), 23-24.

${ }^{5}$ Zul Mubaraq, "Sosiologi Agama", (Malang: Uin-Maliki Press, 2010), 6-7. 
semenjak dari awal kelahiranya dimuka bumi hingga akhir hayatnya. Simbol-simbol dalam agama mejadi ciri khas dan piroritas dalam masyarakat yang di pegang teguh oleh setiap pemeluknya. ${ }^{6}$

Kebutuhan masyarakat terhadap agama menjadi hal yang wajar, karena agama memegang peranan penting dalam kehidupan masyarakat yang berhubungan dengan rohani yang sulit di penuhi oleh material, sekuler dan ilmu pengetahuan lainnya. Dasar dari struktur agama adalah pemujaan kepada sang ilahi yang tidak dapat dipisahkan dalam kehidupan sehari-hari masyarakat. Dan agama tidak hanya berbicara tentang aspek sugrawi semata akan tetapi duniawi yang menjadi dorongan manusia untuk berperilaku sesuai dengan syariat ajaran agamanya. ${ }^{7}$

Agama bagian dari masyarakat, agama mengambil andil dalam membentuk karakter masyarakat secara empiris atau non empiris. Maka keberadaan agama dalam masyarakat dinyatakan sebagai sistem sosial yang di buat oleh setiap penganutpenganut agama yang berporos pada kekuatan non empiris yang di percayai oleh masyarakat alat untuk mencapai tujuan dari pada keselamatan diri dan para pengautnya. ${ }^{8}$ Maka dalam hal ini dapat kita lihat bagaimana agama mempengaruhi masyarakat dan bagaimana masyarakat membutuhkan agama secara spiritualisme atau non spiritualisme.

\section{Agama Hinduisme Dan Buddhaisme}

Kehidupan beragama dan bermasyarakat merupakan fenomena universal dalam kehidupan manusia. Masyarakat beragama di dunia mempercayai bahwasanya setiap agama yang dianutnya mempunyai peran dan fungsi yang singnifikan dalam kehidupan untuk mendapatkan keselamatan dan kebahagian hidup dunia dan akhirat. Mereka juga menyakini setiap agama mengajarkan tentang kedamaian dan kasih sayang terhadap sesama mahluk individu yang saling membutuhkan satu dengan yang lain dan seluruh mahluk Tuhan di Muka ini. ${ }^{9}$

Konsep agama dalam masyarakat Hinduisme dan Buddhaisme sama yaitu konsep tentang sebuah aturan yang membawa kebenaran keselamatan dunia akhirat. Namun secara peraktik keagamaan dari kedua agama ini berbeda, tergantug bagaimana agamanya yang mengajarakan peraktik-peraktik tersebut. Maka difinisi agama adalah sebuah system keyakinan yang di anut oleh setiap individu atau masyarakat tertentu yang

\footnotetext{
${ }^{6}$ Adi Rahmat \& Rosita Andini, "Pengantar Sosiologi Agama", 1-3

${ }^{7}$ Petrus Lakonawa, "Agama Dan Pembentukan Cara Pandang Serta Perilaku Hidup Masyarakat", Humaniora, Vol. 4, No. 2 (Oktober 2013), 5.

8 I Ketut Margi, "Kebebasan Beragama Di Indonesia: Antara Asa Dan Aktualita", Jurnal IImiah Penelitian Pendidikan Dan Sosiologi, Vol. 3, Nomor 2 (November, 2019), 4.

${ }^{9}$ Shonhaji, "Agama Sebagai Perekat Sosial Pada Masyarakat Multikutural", $A L=A d y a n / V o l . / V I I$, No. 2, (Juli-Desember/2021), 2.
} 
mengwujudkan tindakan dalam suatu masyarakat untuk menginterprestasikan dan memberikan respon terhadap keyakianan sebagai hal yang suci. ${ }^{10}$

Agama di Indonesia memang berperan sangat penting dalam kehidupan masyarakat. Hal ini di wujudkan dalam sebuah idologi bangsa Indonesia yakni Ketuhan yang maha esa. Berdasarkan hasil sensus penduduk pada tahun 2018 di Indonesia terdapat $86,7 \%$ dari 267.670. 543 penduduk Indonesia memeluk agama Islam, 7,6\% pemeluk agama Kristen protestan, 3, 13\% pemeluk agama kristen katolik, 1,74\% pemeluk agama hindu, 0,77\% pemeluk agama Budhha dan 0, 04\% pemeluk agama konghucu. ${ }^{11}$

Berdasarkan data diatas menunjukkan Indonesia merupakan Negara yang multi agama dan setiap agama mempunyai penganut. Durkheim melihat agama sebagai sesuatu yang sacral dan profan. Agama yang sacral yaitu agama yang berhubungan dengan yang suci yakni Tuhan yang berada di luar jangkauan pikiran manusia. Sedang agama profane adalah agama yang yang berhubungan dengan dunia dan kekhidupan nyata dalam kehidupan sehari-hari yang berada di bawah kendali manusia seperti paraktik-peraktik ritual keagamaan yang dilakukan oleh masyarakat beragama. ${ }^{12}$

agama hinduisme dan buddhaisme merupakan agama besar di dunia setelah agama Kristen dan islam. Hal ini ditunjukkan dengan $15 \%$ populasi dunia yang beragama hindu dan $7 \%$ beragama Buddha. Kedua agama ini mempunyai perbedan dalam hal perspektif Tuhan, moralitas, dan system kasta. ${ }^{13}$ kemudian persamaan dari kedua agama ini adalah sama-sama muncul di india dan berkembang di sana yang kemudian menyebar kenegara lain termasuk Indonesia. Adanya dasar kebenaran dalam ajaran agama hindu dan Buddha yang menyelamatkan umat manusia dari kegelapan. Mendorong setiap perilaku tidak boleh keluar dari ajaran agama yang di yakini mereka oleh masing-masing agama tersebut. ${ }^{14}$

Hinduisme merupakan agama tertua di asia yang disebut juga dengan agama hindu. Dalam agama hindu terdapat beberapa aliran seperti salwa, waisnawa, sakta dan mengenai pandangan terhadap hukum dan aturan moralitas dalam kehidupan sehari-hari. Dalam konteks Bahasa arab agama hinduisme berasal dari al-hind yang

10 Dwi Narwoko \& Bagong Suyanto, "Sosiologi Teks Pengantar Dan Terapan", (Jakarta: Prenadamedia Group, 2014), 249.

11 Wikipedia, "Agama Di Indonesia", Di Akses 17 Juni 2021

12 Sindung Haryanto, "Sosiologi Agama: Dari Klasik Hingga Postmofern”, (Yogyakarta: Ar-Ruzz Media 2015), 22.

${ }^{13}$ Edelweiss Lararenjana, "Perbedaan Hindu Dan Buddha Yang Sangat Menarik ", Di Akses 17 Juni (2021), [Https://M.Merdeka.Com].

${ }^{14}$ Ipul, "Perbedaan Agama Hindu Dan Buddha Juga Persamaannya Di Lengkapi Table", Di Akses, 17 Juni (2021), [Https://IImubelajar.Com]. 
digunakan untuk menyebut suku bangsa yang ada di India, sedangkan hindu atau hindu digunakan sejak 18 abad yang lalu. ${ }^{15}$

penelitian delima sari penggabean, dengan tema hubungan pemahaman siswa tentang lahir dan berkembangnya agama hindu-buddha Di Indonesia dengan muncul dan berkembangnya kerajaan hindu Buddha di Indonesia di kelas XI SMK negeri 3 Sibolga. Mengambarkan sejarah kemunculaan agama hindu dan Buddha di Indonesia yang sampai sekarang masih berkembang. Dalam sejarah kehadiran kedua agama ini di Indonesia karena kehadiran orang india yang menganut hindu dan Buddha datang ke Indonesia dan akhirnya orang Indonesia juga banyak pergi ke india untuk berziarah dan belajar agama hindu dan Buddha dan setelah kembalinya pun ajaran dari kedua agama tersebut disebar luaskan di Indonesia. Maka berdasarkana histori kehadiran hindu dan buddha adi Indonesia karena telah terjalinya hubungan yang erat antara Indonesia dengan india. ${ }^{16}$

Berdasarkan sejarah agama hindu di latar belakangi oleh akulturasi antara suku arya dengan bangsa iran dan dravida sebagai penduduk asli di india waktu itu. Bangsa arya pada tahun 1500 SM masuk ke india dengan membawa kepercayaan dan kebudayaan yang bersifat vedawi yang telah menjadi thesa dan kepercayaan terhadap dravida dianalisis menjadi antitesa. Kemudian dari sinkritisme maka lahirlah agama hinduisme sebagai sytesa. Pada waktu bangsa arya sebagai pendatang, penduduk india lokal dan bangsa dravida. ${ }^{17}$

Secara Bahasa Hindu berasal dari kata sanskerta yaitu sindhu. Dan dalam bahasa Persia pada abad pertengahan dimana hindu merujuk pada kata avestan kuno hendava (sankerta sindhu) yang bermakna penghuni sungai sindhu. ${ }^{18}$ Sedangkan agama Buddhaisme adalah sebuah agama yang mempunyai faham nonteisme atau filsafat yang berasal dari bagian timur anak benua india yang ajarannya berlandaskan pada Siddhartha Gautama. Penyebaraan agama Buddha di india sekitar 6 abad sebelum masehi. Agama ini adalah agama terbesar setelah agama hindu di dunia. Ajaran yang terdapat apada agama Buddha meliputi dri tradisi, keyakinan, dan kepercayaan sebagai peraktik spiritual pada ajarannya. ${ }^{19}$

Kehidupan dari perkembangan hindu dan budhda di Indonesia mempunyai ciri khas dan corak yang berbeda juga unik. Namun mereka mampu hidup berdampingan

${ }^{15}$ Wikipedia, "Agama Hindu", Diakses 17 Juni (2021), [Https://ld.M.Wikipedia.Org].

${ }^{16}$ Delima Sari Penggabeaan, "Hubungan Pemahamaan Siswa Tentang Lahir Dan Berkembangnya Agama Hindu-Buddha Di Indonesia Dengan Muncul Dan Berkembangnya Kerajaan Hindu Buddha Di Indonesia Di Kelas XI SMK Negeri 3 Sibolga”, Jurnal Pendidikan IPS, (2017), 3.

${ }^{17}$ Khotimah, "Agama Hindu Dan Ajar-Ajarannya", Perpustakaan Nasional RI, (Daulat Riau 2013), 6.

${ }^{18}$ Wikipedia, Umat Hindu" Diakses 17 Juni (2021), [Https://ld.M.Wikipedia.Org].

${ }^{19}$ Wikipedia, "Agama Buddha”, Diakses 17 Juni (2021), [Https://ld.M.Wikipedia.Org] 
dan tidak menimbulkan permasalahan dan pepecahan di antara kedua agama tersebut. Mesikipun di dalam lingkungan kekuasan ras sering kali terjadi perpecahan akibat dari keingian menguasai tahta dan berkuasa. Namun hal ini tidak mempengaruhi kehidupan mereka. Hal ini terbukti dengan adanya isi prasati sebagai lembang toleransi beragama umat hindu dan buddha. ${ }^{20}$

Sosiologi agama memberikan pandangan terhadap agama yang memberikan perannya tehadap kehidupan manusia dalam teori fungsionalnya, agama menjadi sangat penting karena berhubungan dengan unsur pengalaman hidup manusia yang di dapatkan dari ketidak pastian menuju karakteristik fundamental terhadap kondisi manusia. Maka fungsi dari agama adalah menyediakan cakralawa mengenai dunia luar yang sifatnya dapat di jangkau oleh manusia. Dan ritul yang berhubungan dengan jaminan keselamatan-keselamatan untuk setiap penganutnya bagi yang telah mempertahkan moralnya. ${ }^{21}$

Dalam agama hinduisme dan buddhaisme terdapat simbol-simbol tertentu yang membedakan dari keduanya. Reprentasi simbol dari tradisi setiap agama berguna untuk membangun konsep plualisme dan mulitultualisme dalam kehidupaan masyarkat beragama. Disini dapat kita lihat simbol dari agama hinduisme dengan buddhaisme berbeda diantaranya hinduisme bersimbol "om". Kata "om atau aum" dalam agama hinduisme mengambarkan tentang entitas misltik yang mencakup Upanishad. Umat hindu percaya pada saat penciptaan dimulai dengan kesadaran ilahi yang meliputi segala bentuk getaran yang asli dan bermanifestasi sebagai "om". Mereka juga menyakini sebelum penciptaan terdapat "shunyakasha", kekosongan dan kehampaan. Getaran dari "om" melambangkan manifestasi Tuhan alam bentuk saguna brahmana. Istilah "om' juga bagian dari cerminan dari realitas absolut yang menyatakan Tuhan mahakuasa, dan istilah "aum' mengambarkan dari energy ilahi yang disatukan dalam tiga aspek yaitu brahmana Shakti (penciptaan), wisnu Shakti (pelestarian), dan shiva Shakti (pembebasaan atau penghancuran). ${ }^{22}$

Kemudian simbol dari Buddhaisme adalah roda dharma. Simbol ini digunakan sebagai konsep dharma sejak ke-3 SM. Simbol ini mewakili ajaran Buddha Gautama tentang jalan menuju Nirwana, yang terhubung dalam lambing organisasi buddhaisme di india, sri lanka dan Mongolia. Dan ini juga mewakili tradisi agama buddha sebagai simbol pendeta militer amerika serikat tahun 1990. Simbol Buddha ini berasal dari

${ }^{20}$ Linda Wahyuning Tiyas, "Prasasti Peninggalan Kerajaan Yang Bercorak Hindu-Buddha Yang Mengambarkan Keharmonisaan Agama Hindu-Buddha", (skripsi: Fakuktas IImu Sosial Unversitas Negeri Semarang 2017), 1

21 Zulfi Mubaraq, "Sosiologi Agama”, (Malang: Uin Maliki Press, 2015), 55

22 Https://En.Wikipedia.Org/Wiki/Religious-Simbol, Diakse 17 Juni 2021 
sansekerta dharma yang diambil dari kata memangang, memelihara dan diartikaan apa yang ditetapkan atau teguhkan karena hukum berasal adri kita sansekerta veda. ${ }^{23}$

Para antropologi memberikan difinisi mengenai agama sebagian dari dinamika dalam persoalan keagaman sangat dekat dengan budaya yang berkembang di tengah masyarakat. ${ }^{24}$ Dalam hal ini antopologi melihat fenomena keagaman melalui simbolsimbol dan perilaku yang terjadi dalam aktivitas sehari-hari masyarakat beragama. Misalnya dalam komunitas agama hinduisme sebagian besar berada di desa dan kota yang pernah menjadi bagaian dari kerajan hindu kuno di jawa timur , Sumatra dan lainlain. ${ }^{25}$

Agama menjadi kebutuhan manusia secara individu atau kelompok yang bersifat sebagai tanda kelemahanya yang membutuhkan kekuatan yang absolut dalam proses perjalanan hidupnya.agama selain berbicara mengenai kesakralan juga berbicara mengenai aktualisasi realitas sosiologis. Dalam sosiologi pengetahuan karl mannheim, salah satu dari kebenaran agama adalah ketika diskursus kebenaran ditarik dari soal objektivitas dan subjektivitas menuju sejauh mana kebenaran yang cerminan pembebasan terhadap kaum tertindas yang landaskan pada komitmen emansipatoris dan dilog yang di dasari oleh komitmen solidaritas. ${ }^{26}$

\section{Ajaran Agama Hinduisme Dan Buddhaisme}

Dalam penelitian ibg yudha triguna yang membahas "konsep keselamatan dan kemanusiaan dalam hindu". Penelitian mengambarkan konsep ketuhanan dalam agama hindu dan hubungan dengan manusia. Agama hindu merupakan agama yang mempunyai keyakinan kepada satu Tuhan namun di beri nama dengan brahmana dan lainnya. Kepercayaan agama hindu terhadap tuhan di eksperikan melalui acara ritualritual keagamaan yang persembahkan. Dalam penelitian ini melihat hindu sebagai agama yang politeisme dan agama yang memuja banyak Tuhan meskipun agama ini meyakini satu Tuhan . Namun dalam peresentasinya meraka menyembah banyak Tuhan. ${ }^{27}$

Kemudian penelitian Sindhu kusalanana yang gambarkan pada sejarah pada ritual keselamatan methik. Dalam hal ini ia menjelaskan mengenai simbol dari bentuk keselamatan tersebut. Ritual yang dilakukan oleh agama Buddha adalah sebagai simbol untuk meningkatkan keyakinan terhadap agamanya. Seperti ritual Buddha yang

\footnotetext{
${ }^{23}$ Dharamachakra", Diakses 17 Juni (2021), [Https://En.Wikipedia.Org/Wiki/Religious-Simbol].

${ }^{24}$ Faddad, Zaki, and Anisatul Mardiah. "Komodifikasi Agama dalam Gerakan Majlis Tafsir AlQur'an (MTA) di Surakarta." Religió: Jurnal Studi Agama-agama 10, no. 1 (2020): 118-139.

${ }^{25}$ Zul Qodir "Sosiologi Agama: Teori Dan Perspektif Keindonesiaan", (Yogyakarta: Pustaka Pelajar, 2018), 2.

${ }^{26}$ Ridwan Lubis, "Sosiologi Agama: Memahami Perkembangan Agama Dalam Interaksi Sosial", (Jakarta: Prenadamedia Group, 2015), 24-25.

27 Ibg Yudha Triguna, "Konsep Keselamatan Dan Kemanusiaan Dalam Hindu", Drarmasmrti, Universitas Hindu Indonesia Denpasar, Nomor 18 Vol. 1 (Mei 2018), 71-73.
} 
berupa kegiatan puja bhakti atau kebaktian. Dimana ritual ini dilakukan untuk meningkatkan keyakinan terhadap tiratana yang dianggap untuk menghindari perbuatan buruk dan melakukan perbuataan baik sebagai langkah untuk mensucikan hati dan pikiraan. ${ }^{28}$

Agama hindu dan buddha merupakan ajaran keagaman yang tidak bisa dipisahkan satu dengan yang lain. Karena kedua agama ini mempunyai sinkretisme yang merupakan sebuah kepecayaan pada masa kerajaan sriwijaya yang di bentuk dengan pertemuan hindu dan buddha. Berdasarkan penenlitian di palembang kelurahaan nomor 9/10Ulu, dimana di palembang terdapat tempat peribadatan umat beragama yang disebut dengaan kelenteng dan vihara yang sangat erat hubunganya dengaan agama hindu dan buddha. ${ }^{29}$

Sistem ketuhan trimurti dalam agama hindu lebih mendekati pada faham materilsme yang sifatnya natualisime berdasarkan pada peristiwa dan kejadian alam, sehingga segala sesuatu itu bergerak secara alami yang di minifestasikan dengan lambang kekuatan. Maha hal ini tidak mengherankan apabila kepercayaan terhadap kekuatan yang majemuk dalam mengiringi ketuhan hindu kearah politisme yang menunjukkan adanya beberapa Tuhan dalam agama hindu yang disebut dengan dewa diantaranya brahmana, wisynu dan syiwa. Kemudian dalam agama hindu mempunyai keyakinan yang kuat terhadap dewanya yang dianggap mempunyai dewa adalah sumber kekuatan yang terkordinasi dalam ketuhan trimurti. 30

Bagi agama Hindu, keselamatan disebut dengan Moksha. Moksha adalah ketika seorang manusia yang tercerahkan dibebaskan dari siklus hidup dan mati (siklus kematian dan reinkarnasi tanpa akhir) dan masuk ke dalam keadaan sempurna. Dia kemudian akan menjadi satu dengan Tuhan. Agar seseorang mencapai moksha, ada beberapa jalan yang selama ini dikenal dalam Hindu, dengan berbuat baik (karma-marga) yang melibatkan pelaksanaan upacara, tugas, dan ritus keagaman tertentu. Tujuannya adalah untuk melakukan pekerjaan tanpa memperhatikan keuntungan pribadi. Dan jalan Pengetahuan (jnana-marga) yang membutuhkan penggunan pikiran dan filosofi untuk mencapati pemahaman yang lengkap tentang alam semesta. Selanjutnya Jalan Pengabdian (bhakti-marga) yaitu Keselamatan dicapai melalui tindakan ibadah, berdasarkan cinta untuk Tuhan (ada ribuah dewa dalam agama Hindu). Dan yang terakhir disebut dengan The Royal Road yaitu Penggunaan teknik meditasi dan yoga.

${ }^{28}$ Sindhu Kusalanana Dkk, " Makna Simbolik Ritual, Selamatan Methik Pari Dalam Pandangaan Agama Buddha Di Desa Gembongaan Kecamataan Ponggok Kabupaten Blitar", Sabbhata Yatra, Jurnal Pariwisata Dan Budaya, Volume 1 Nomor 1 (Juli 2020), 1-3.

${ }^{29}$ Riyardi Maulana Ilham, "Riyardi Maulana Ilham Kajiaan Tentang Situs Klasik Hindu Budha Di Kelurahaan 9/ULU Palembang", Kalpatura: Jurnal Sejarah Dan Pembelajaraan Sejarah, Volume 6, Nomor 1, (Juli 2020), 4-5.

${ }^{30}$ Khotimah, "Agama Hindu Dan Ajar-Ajarannya”, 25. 
Metode mencapai keselamatan ini biasanya hanya digunakan oleh para biksu pengembara.

Umat agama hindu berusaha menyesuaikan diri dengan kewajiban sosial dan ritual menurut aturan perilaku tradisional sesuai kasta, keluarga dan profesi. Hal ini merupakan dharma individu (hukum dan tugas), keseimbangan mendasar seseorang dalam kosmos, alam dan masyarakat. Sanatana (tradisional) dharma adalah istilah Hindu untuk menunjukkan agama mereka, adalah bagaimana seorang Hindu menjalankan praktik keagamaannya. ${ }^{31}$

Thomas Patrick Burke memiliki pandangan bahwa Hinduisme bukanlah satu kesatuan yang utuh dan tunggal, tetapi jumlah dari total kepercayaan dan praktik keagamaan tradisional orang India, yang penuh warna, seperangkat tradisi yang beragam dan kompleks yang di warisi dari sejarah panjang, dan kadang-kadang hanya longgar. Inti dari agama Hindu adalah bahwa ada banyak cara yang berbeda untuk melihat satu objek tidak ada yang akan memberikan keseluruhan pandangan, tetapi masing-masing sepenuhnya valid dalam dirinya sendiri. ${ }^{32}$

Menurut agama Hindu, jiwa (Atma) bersemayam di setiap makhluk hidup. Kematian adalah tubuh dan bukan jiwa, karena jiwa itu abadi. Ketika seseorang meninggal, jiwa memasuki tubuh baru. Tergantung pada karmanya di kehidupan lampau, ia mendapatkan tubuh baru dan mengalami kebahagian atau penderitan lagi. Siklus ini berlanjut sampai jiwa mencapai keselamatan, yaitu kebebasan dari siklus kelahiran dan kelahiran kembali.

Mencapai keselamatan adalah tujuan akhir dari kehidupan seorang Hindu. Dalam Bhagavad-Gita, Sri Krishna telah menjelaskan banyak cara untuk mencapai keselamatan, yang dapat memperoleh keselamtan hanyalah manusia. Kita mendapatkan tubuh manusia ketika jiwa melakukan perjalanan melalui 8.400 .000 spesies. Untuk mencapai keselamatan, seseorang tidak perlu untuk menjadi petama. Meskipun cara yang satu ini sangat terkenal, namun tidak mungkin bagi setiap orang untuk mencela kehidupan normal dan menjadi seorang petapa.

Dharma, Artha, Kama, dan Moksha adalah empat tujuan hidup manusia, di antaranya Moksha adalah tujuan akhir. Setelah memenuhi semua kewajiban terhadap masyarakat dan keluarga, seseorang harus mengalihkan perhatiannya kepada Moksha.

${ }^{31}$ The New Indian Express, The Three Paths Of Hinduism, Diakses Pada Tanggal 19 (Juni 2021), [Https://Www.Newindianexpress.Com/Lifestyle/Spirituality/2012/Jun/17/The-Three-Paths-Of-Hinduism377884. Html]

32 Tahira Basharat, Hinduism And Concept Of Salvation: With Special Reference To The Bhagavad Gita, diakses, 3 juni (2021), 3-4. [Http://Pu.Edu.Pk/Images/Journal/Szic/Pdf Files/1\%20tahira\%20bashart.Pdf ]. 
Semua tindakan harus dilakukan sebagai tugas dalam kerangka aturan masyarakat dan harus mengabdikan semua tindakan kepada Tuhan. ${ }^{33}$

Inti ajaran Hinduisme, terdapat tentang korban dan sajian, sebagai bahan persembahaan, penghormataan terdap arwah nenek moyang yang telah meninggal atau persembahaan dan bentuk penghormatan terhadap dewa. Kemudian korban tersebut yang dilakukan secara umum dalam upacara pembakaran mayat, ketika lagi menghadapi musibah dan lainnya yang dilakukan secara bersama-sama bersama masyarakat setempat. Kemudian korban yang dilakukan secara khusus bersama keluarga dalam upacara perkawinan, kelahiran dan kematian.

Roh dalam ajaran agama hindu disebutkan ada dua, pertama roh brahmana yaitu tuhan penguasa semesta. Kedua roh yang telah terkurung dalam tubuh atau benda yaitu roh Atman. Dalam agama hindu juga ada istilah karma yaitu setiap perbuatan manusia yang baik akan berdampak pada baik dan perbuatan manusia yang jahat akan berdampak pada keburukan. Kemudian diajarakan bahwa kehidupan manusia tidak lepas dari kesangsaran dimana manusia lahir, hidup, berbuat, mati, lahir lagi dan seterusnya. Hal ini akan selalu berputar dan tidak akan berhenti kecuali dengan kelepasan. Kelepasan disebut moksa yaitu jalan menghindari kesangsaraan dan cara membebaskan diri dari godaan, keingiaan yang melekat dalam diri manusia. ${ }^{34}$

Agama buddhaisme merupakan agama yang mempunyai ajaraan mengenai kehidupan beragama yang beragam menuju jalan kebenaraan dan keselamatan untuk menemukan jalan yang mulia. Dalam agama buddha memperbaiki diri adalah jalan untuk menuju jalan yang mulia dengan melakukan puasa yang dikenal dengan upasatha yang bermakna masuk untuk berdiam atau menahan diri untuk tidak membunuh seluruh mahluk hidup, menahan diri untuk tidak mencuri, melatih untuk melakukan hubungan seksual dengan pasangan yang sah, menahan untuk tidak berbohong, menahan untuk tidak minum dan makanaan yang memabukkan, menghindari makanan setelah lewat tengah hari, menahan diri untuk tidak duduk dan tidur di tempat yang mewah. Hal ini merupakan sila dalam agama buddha ketika melaksankaan puasa yang harus di taati untuk mendapatkan ketentraman untuk pemberishan diri dari perbuatan buruk dan kotor. ${ }^{35}$

Inti dari ajaran buddhaisme adalah menunjukan bahwa hidup manusia tidak luput dari penderitan, kelahiran, kesakitan, usia tua, dan kematian. Penderitan yang di hadapi manusia dalam pandangan agama buddha lahir karena ada sebuah keinginan dan untuk

33 Rahul, Salvation, Diakses Tanggal 3 Juni (2021), Pukul 17.23 WIB. [Https://Www. Hinduismfacts. Org/Reincarnation/Salvation/]

${ }^{34}$ Abudullah Ali, “ Agama Dalam IImu Perbandingan", (Bandung: Nuansa Aulia, 2007), 162-163.

${ }^{35}$ Ali Mursyid Aziz \& M. Yusuf, "Penyuciaan Diri Dalam Buddha, Hindu, Dan Islam", Al-Hikmah: Jurnal Studi Agama-Agama, Vol. 7. Nomor 1, (2020), 4-5. 
menghilangkan penderitan tersebut seorang harus menlenyapkan keingiannya untuk sampai kepada kebagian yang disebutnya dengan nirwana. Dan untuk dapat menlenyapkan keinginan Nirwana, seseorang harus dapat menempuh delapan jalan utama yaitu bepengertian yang benar, berpikir yang benar, berkata yang benar, berbuat yang benar, bermata pencarian yang benar, berusaha yang benar, memperhatikan halhal yang benar, dan memusatakan pemikiran yang benar. ${ }^{36}$

Agama Buddhisme mempunyai tujuan untuk pembebasan dari penderitan dengan membebaska diri dari samsara. Banyak jenis Buddhisme, Theravada, Mahayana, dan Vajrayana (Tantra), menekankan meditasi individu dan pembebasan selanjutnya dari samsara, yang menjadi tercerahkan. Namun, tradisi Tanah Suci dari Buddhisme Mahayana umumnya berfokus pada sifat penyelamatan Amitabha Buddha Surgawi. Dalam eskatologi Buddhis, diyakini bahwa kita saat ini hidup di zaman akhir hukum, periode 10.000 tahun di mana sifat manusia yang rusak berarti ajaran Buddha tidak di dengarkan. Sebelum era ini, Bodhisattva Amitabha membuat 48 sumpah, termasuk sumpah untuk menerima semua makhluk yang di panggil kepadanya, untuk mengizinkan mereka berlindung di Tanah Sucinya dan untuk mengajari mereka dharma murni. Oleh karena itu dianggap tidak efektif untuk mempercayai meditasi pribadi dan bahkan praktik monastik, tetapi hanya percaya pada sumpah utama Amitabha. ${ }^{37}$

\section{Implementasi sosiologi agama terhadap kehidupan beragama}

sosiologi agama merupakan studi yang mengakaji tentang hubungan timbal balik antara umat beragama. Fenomena keagamaan dalam masyarakat menjadikan sosiologi agama mengambil peran untuk melihat agama dari segala arah untuk memberikan difinisi agama yang multikultural bukan yang bersifat tunggal. Sosiologi berpandangan bahwa agama mempunyai fungsi yang bersifat manifest dan laten. ${ }^{38}$ Agama merupakan suatu sistem kepercayaan yang terwujud dalam perilaku sosial masyarakat. agama erat kaitannya dengan pengalaman seseorang atau masyarakat. sebagaimana peter I berger mengambarkan merupakan kebutuhan dasar manusia untuk membela dirinya dari kekacauan. ${ }^{39}$

\footnotetext{
${ }^{36}$ Abudullah Ali, “ Agama Dalam IImu Perbandingan”, 168-169.

37 Agama Buddha. Diakses Tanggal 03 Juni (2021), Pukul 19.35 WIB. [Https://En.Wikipedia.Org/Wiki/Soteriology].

${ }^{38}$ Inas Rizqi, "Pandangan Sosiologi Agama Terhadap Toleransi Antar Umat Beragama Di Kampong Sawah, Bekasi”, Diakses 29 Juli (2021), [Https://Scholar.Google.Com/Scholar?HI=Id\&As Sdt=0\%2C5\&Q=Sosiologi+Agama+Terhadap+Kehidupa n+Beragama\&Btngl.

${ }^{39}$ Rizal Mubit, "Peran Agama Dalam Multicultural Masyarakat Indonesia”, Jurnal: Episteme, Vol. 11. No. 1 (Juni 2016), 13. DOI: 10.21274/Epis.2016.11.1.163-184.
} 
Kehadiran sosiologi agama memberikan pandangan kepada umat beragama tentang agama bersifat universal. Sehingga timbul ungkapan-ungkapan tentang plualisme, toleransi antara beragama dan lainnya. Sosiologi agama menawarkan bagaimana merawat kemajemukaan dalam agama. Karena setiap agama di tuntut untuk hidup dalam kerukunan, kedamaian dan keselamatan. Misalnya kasus agama Hindu.

Agama hindu di tuntut untuk mengembangkan hidup rukun sebagaimana yang terkandung dalam kitab Weda dan beberapa tafsiran yang tertera seperti "aku satukan pikiran dan langkah mu mengwujudkan kerukunan di antara kamu. Aku bimbing mereka yang berbuat salah menuju jalan yang benar". Berdasarkan hal ini dapat kita cermati bersama setiap agama megajarkan tentang kerukunan dan hidup berdampingan dengan damai. Hal-hal yang demikian tidak hanya di temukan pada ajaran agama Islam yang selama ini sering kita jadikan landasan dalam berargument menjatuhkan agama yang lain. 40

Sosiologi agama tidak menjustifikasi mana yang salah dan benar. Sosiologi memberikan arahan kepada umat beragama tentang sebuah kedamaian dan kebahagian hidup rukun. Meskipun sampai hari ini konflik antara umat beragama belum bisa di hilangkan namun setidaknya sosiologi agama memberikan pelajaran kepada manusia dalam memahami makna agama dalam kehidupan masyarakat. ${ }^{41}$

Sosiologi agama mampu memberikan pemahaman tentang fenomena keagamaan dalam kehidupan masyarakat. Sosiologi agama mengarahkan manusia menuju jalan yang pluralisasi agama dan dapat mengungkapkan struktual dari sikap keagamaan sekelompok masyarakat atau individu..$^{42}$ sosiologi agama memagang peran penting dalam kehidupan umat beragama, tanpa adanya sosiologi yang mempu membuka pikiran cakralawa manusia yang hetrogen maka konflik-konflik keagamaan dalam masyarakat tidak akan dapat teratasi.

\section{KESIMPULAAN}

Agama menjadi warna yang sudah melekat dalam kehidupan masyarakat. Agama menjadi kebutuhan yang dijadikan pedoman oleh setiap pemeluknya untuk mendapatkan kehidupan yang rukun damai, tenteram dan sejahtera di duni sampai akhirat. Agama Hinduisme dan Buddhaisme merupakan agama besar dunia setelah Islam yang lahir di India dan dilatar belakangi akulturasi yang di bawa dari iran ke india. Kedua agama ini

40 Suprapto, "Agama \& Studi Perdamaian Plualisme, Kearifan Beragama Dan Resolusi Konflik", (Mataram: LEPPIM, 2016), 74.

${ }^{41}$ Agus Machfud Fauzi, "Sosiologi Agama”, (Surabaya: UNESA, 2017), 8-9.

42 Moh. Soehadha, "Menuju Sosiologi Beragama: Paradigma IImu Dan Tantangan Kontemporer Sosiologi Agama Di Indonesia" Jurnal Sosiologi Agama:Jurnal Ilmiah Sosiologi Agama Dan Perubahan Sosial, Vol. 15. No. 1 (Januari-Juni, 2021), 15-16. 
mempunyai cara tersendi dalam ranah spiritualnya untuk sampai kepada kebahagiaan dan keselamatan.

Setiap ajaran dalam keagamaan tersebut mempunyai ajaran-ajaran tertentu untuk mendekatkan diri kepada Tuhanya. Agama dalam hinduisme dan buddhaisme berperan penting dalam memperentasikan kehidupan bersama dalam keragaman dan membina kehidupan yang damai saling berdampingan satu dengan yang lain. Agama di jadikan sebagai motivasi utama dalam bertindak ynag berhubungan dengan diri sendiri masyarakat bahkan terhadap tuhannya. 


\section{DAFTAR RUJUKAN}

Agama Buddha. Diakses Tanggal 03 Juni (2021),Pukul 19.35 WIB. Https://En.Wikipedia.Org/Wiki/Soteriology. 2007.

Ali, Abudullah. "Agama Dalam Ilmu Perbandingan”. Bandung: Nuansa Aulia.

Bagong Suyanto, \& Dwi Narwoko. "Sosiologi Teks Pengantar Dan Terapan". Jakarta: Prenadamedia Group. 2014.

Basharat, Tahira. Hinduism And Concept Of Salvation: With Special Reference To The Bhagavad Gita, diakses, 3 juni (2021). Http://Pu.Edu.Pk/Images/Journal/Szic/Pdf Files/1-\%20tahira\%20bashart.Pdf

Bunyamin, Bubun. "Konsep Keselamatan Dalam Agama-Agama Ibrahim (Yahudi, Kristen, Dan Islam)". Skripsi: Uinversitas Islam Negeri Sunan Gunung Jati Bandung, (2013). Simbol.

Dharamachakra. Diakses 17 Juni (2021). Https://En.Wikipedia.Org/Wiki/Religious-

Https://En.Wikipedia.Org/Wiki/Religious-Simbol. Diakse 17 Juni (2021)

Faddad, Zaki, and Anisatul Mardiah. "Komodifikasi Agama dalam Gerakan Majlis Tafsir Al-Qur'an (MTA) di Surakarta." Religió: Jurnal Studi Agama-agama 10, no. 1 (2020): 118-139.

Fauzi, Agus Machfud. "Sosiologi Agama”. Surabaya: UNESA, 2017.

Haryanto, Sindung. "Sosiologi Agama: Dari Klasik Hingga Postmofern". Yogyakarta: Ar-Ruzz Media . 2015.

Ilham, Riyardi Maulana. "Riyardi Maulana Ilham Kajiaan Tentang Situs Klasik Hindu Budha Di Kelurahaan 9/ULU Palembang". Kalpatura: Jurnal Sejarah Dan Pembelajaraan Sejarah. Volume 6. Nomor 1. Juli (2020).

Ipul. "Perbedaan Agama Hindu Dan Buddha Juga Persamaannya Di Lengkapi Table", Di Akses, 17 Juni (2021), Https://llmubelajar.Com

Khotimah. "Agama Hindu Dan Ajar-Ajarannya". Perpustakaan Nasional RI. Daulat Riau (2013)

Lakonawa, Petrus. "Agama Dan Pembentukan Cara Pandang Serta Perilaku Hidup Masyarakat". Humaniora, Vol. 4, No. 2 Oktober (2013).

Lararenjana, Edelweiss. " Perbedaan Hindu Dan Buddha Yang Sangat Menarik ". Di Akses 17 Juni (2021), Https://M.Merdeka.Com

Lubis, Ridwan. "Sosiologi Agama: Memahami Perkembangan Agama Dalam Interaksi Sosial”. Jakarta: Prenadamedia Group .2015. 
M. Yusuf \& Ali Mursyid Aziz. "Penyuciaan Diri Dalam Buddha, Hindu, Dan Islam". Al-Hikmah: Jurnal Studi Agama-Agama, Vol. 7. Nomor 1. (2020)..

Margi, I Ketut . "Kebebasan Beragama Di Indonesia: Antara Asa Dan Aktualita". Jurnal IImiah Penelitian Pendidikan Dan Sosiologi. Vol. 3, Nomor 2 November (2019).

Mubaraq, Zul. "Sosiologi Agama”. Malang: Uin-Maliki Press. 2010.

Mubit, Rizal. "Peran Agama Dalam Multicultural Masyarakat Indonesia", Jurnal: Episteme. Vol. 11. No. 1 Juni (2016). 13. DOI: 10.21274/Epis.2016.11.1.163-184.

Penggabeaan, Delima Sari. "Hubungan Pemahamaan Siswa Tentang Lahir Dan Berkembangnya Agama Hindu-Buddha Di Indonesia Dengan Muncul Dan Berkembangnya Kerajaan Hindu Buddha Di Indonesia Di Kelas XI SMK Negeri 3 Sibolga", Jurnal Pendidikan IPS, (2017).

Qodir, Zul. "Sosiologi Agama: Teori Dan Perspektif Keindonesiaan". Yogyakarta: Pustaka Pelajar, 2018.

Rahul. "Salvation". Diakses Tanggal 3 Juni (2021), Pukul 17.23 WIB. Https:/Nww.Hinduismfacts.Org/Reincarnation/Salvation/.

Rizqi, Inas. "Pandangan Sosiologi Agama Terhadap Toleransi Antar Umat Beragama Di Kampong Sawah, Bekasi”, Diakses 29 Juli (2021), [Https://Scholar.Google.Com/Scholar?HI=Id\&As Sdt=0\%2C5\&Q=Sosiologi+Agama+Ter hadap+Kehidupan+Beragama\&Btngl. (2015).

Rosita Andini, Adi Rahmat. "Pengantar Sosiologi Agama". Jakarta, Lpp Press.

Shonhaji. "Agama Sebagai Perekat Sosial Pada Masyarakat Multikutural". $A L=$ Adyan/Vol./VII, No. 2. (Juli-Desember. (2021).

Sindhu Kusalanana Dkk. "Makna Simbolik Ritual, Selamatan Methik Pari Dalam Pandangaan Agama Buddha Di Desa Gembongaan Kecamataan Ponggok Kabupaten Blitar", Sabbhata Yatra, Jurnal Pariwisata Dan Budaya, Volume 1 Nomor 1 Juli (2020).

Soehadha, Moh. "Menuju Sosiologi Beragama: Paradigma Ilmu Dan Tantangan Kontemporer Sosiologi Agama Di Indonesia". Jurnal Sosiologi Agama:Jurnal IImiah Sosiologi Agama Dan Perubahan Sosial. Vol. 15. No. 1 Januari-Juni. (2021).

Suprapto. "Agama \& Studi Perdamaian Plualisme, Kearifan Beragama Dan Resolusi Konflik". Mataram: LEPPIM. 2016.

The New Indian Express, The Three Paths Of Hinduism, Diakses Pada Tanggal 19 Juni (2021). Https://Www.Newindianexpress.Com/Lifestyle/Spirituality/2012/Jun/17/TheThree-Paths-Of-Hinduism-377884.Html

Tiyas, Linda Wahyuning. "Prasasti Peninggalan Kerajaan Yang Bercorak HinduBuddha Yang Mengambarkan Keharmonisaan Agama Hindu-Buddha". skripsi: Fakuktas IImu Sosial Unversitas Negeri Semarang (2017). 
Triguna, Ibg Yudha. "Konsep Keselamatan Dan Kemanusiaan Dalam Hindu", Drarmasmrti, Universitas Hindu Indonesia Denpasar, Nomor 18 Vol. 1 Mei . (2018).

Widia astuti, Kadek. "Hubungan Agama Dalam Kehidupan Masyarakat Bali", VIDYA DARS'AN: Jurnal Mahasiswa Filsafat Hindu, Volume 2, No. 1 November (2020).

Wikipedia, “Agama Hindu”, Diakses 17 Juni (2021), Https://ld.M.Wikipedia.Org

Wikipedia. "Agama Buddha". Diakses 17 Juni (2021). Https://ld.M.Wikipedia.Org.

Wikipedia. "Agama Di Indonesia". Di Akses 17 Juni (2021).

Wikipedia. Umat Hindu" . Diakses 17 Juni (2021). Https://ld.M.Wikipedia.Org

Yuliana. "Menjaga Kerukunaan Dalam Multikulturalisme Beragama: Universitas Udayana Prosiding Webinar Nasional IANH-TP Palangkaraya". No.2 Tahun . (2021). Https://Prosiding.lahntp.Ac.Id, ISBN: 978-623-90547-8-6

Zulfi Mubaraq, "Sosiologi Agama”. Malang: Uin Maliki Press. 2015. 